Communities of Grain 


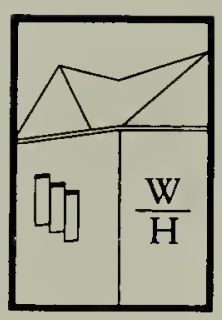

The Wilder House Series

In Politics, History

AND CULTURE

The Wilder House Series is published in association with the

Wilder House Board of Editors and the University of Chicago.

David Laitin, Editor

Leora Auslander, Assistant Editor

George Steinmetz, Assistant Editor

Communities of Grain: Rural Rebellion in Comparative Perspective by Victor V. Magagna

\section{ALSO IN THE SERIES}

State and Society in Medieval Europe: Gwynedd and Languedoc under Outside Rule by James Given

Language and Power: Exploring Political Cultures in Indonesia by Benedict R. O'G. Anderson

Reclaiming the Sacred: Lay Religion and Popular Politics in Revolutionary France by Suzanne Desan 


\section{Communities of Grain}

\section{RURAL REBELLION IN \\ COMPARATIVE PERSPECTIVE}

\section{Victor V. Magagna}

Cornell University Press

ITHACA AND LONDON 


\section{Copyright (C) I99I by Cornell University}

All rights reserved. Except for brief quotations in a review, this book, or parts thereof, must not be reproduced in any form without permission in writing from the publisher. For information, address Cornell University Press, I 24 Roberts Place, Ithaca, New York I4850.

First published I99 I by Cornell University Press.

International Standard Book Number 0-80 I 4-236 I-9

Library of Congress Catalog Card Number 90-55720

Printed in the United States of America

Librarians: Library of Congress cataloging information appears on the last page of the book.

(2) The paper in this book meets the minimum requirements of the American National Standard for Information Sciences-

Permanence of Paper for Printed Library Materials, ANSI Z39.48-I984. 
TO TERMINUS,

SPIRIT OF BOUNDARIES

AND TERRITORIAL JUSTICE 
